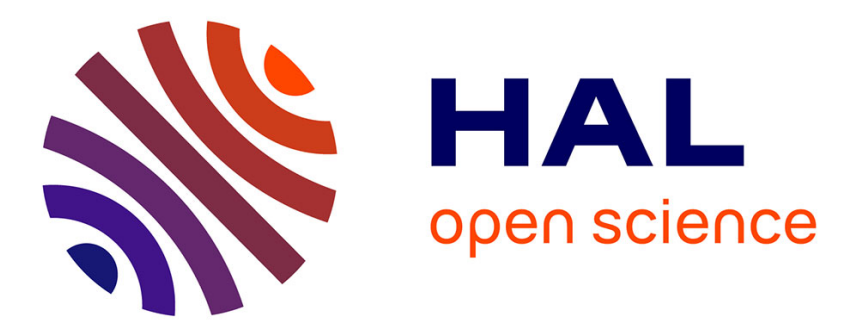

\title{
Multi-scale archaeogenetic study of two French Iron Age communities: From internal social- to broad-scale population dynamics
}

Claire-Elise Fischer, Marie-Helene Pemonge, Frédéric Santos, Harmony Houzelot, Christine Couture-Veschambre, Anthony Lefort, Stéphane Rottier, Marie-France Deguilloux

\section{To cite this version:}

Claire-Elise Fischer, Marie-Helene Pemonge, Frédéric Santos, Harmony Houzelot, Christine CoutureVeschambre, et al.. Multi-scale archaeogenetic study of two French Iron Age communities: From internal social- to broad-scale population dynamics. Journal of Archaeological Science: Reports, 2019, 27, pp.101942. 10.1016/j.jasrep.2019.101942 . hal-02862853

\section{HAL Id: hal-02862853 https://hal-inrap.archives-ouvertes.fr/hal-02862853}

Submitted on 25 Oct 2021

HAL is a multi-disciplinary open access archive for the deposit and dissemination of scientific research documents, whether they are published or not. The documents may come from teaching and research institutions in France or abroad, or from public or private research centers.
L'archive ouverte pluridisciplinaire HAL, est destinée au dépôt et à la diffusion de documents scientifiques de niveau recherche, publiés ou non, émanant des établissements d'enseignement et de recherche français ou étrangers, des laboratoires publics ou privés.

\section{(ㄷ)(1) $(5$}

Distributed under a Creative Commons Attribution - NonCommerciall 4.0 International 
1 Multi-scale archaeogenetic study of two French Iron Age communities: from internal social- to

2 broad-scale population dynamics

3 Claire-Elise Fischer ${ }^{a},{ }^{*}$, Marie-Hélène Pemonge ${ }^{a}$, Frédéric Santos ${ }^{a}$, Harmony Houzelot ${ }^{a}$, Christine

4 Couture-Veschambre ${ }^{\mathrm{a}}$, Anthony Lefort ${ }^{\mathrm{b}}$, Stéphane Rottier ${ }^{\mathrm{a}}$ and Marie-France Deguilloux ${ }^{\mathrm{a}}$

5 a De la Préhistoire à l'Actuel, Culture, Environnement, Anthropologie - UMR 5199, CNRS, Université

6 de Bordeaux, Allée Geoffroy Saint-Hilaire, CS 50023, 33615 Pessac Cedex, France

$7 \quad{ }^{b}$ Inrap Grand-Ouest, Boulevard de l'Europe, Bourguébus, France

$8 \quad *$ claire-elise.fischer@u-bordeaux.fr (C.-E. Fischer)

9 marie-helene.pemonge@u-bordeaux.fr (M.-H. Pemonge)

10 frederic.santos@u-bordeaux.fr (F. Santos)

11 monyh@hotmail.fr (H. Houzelot)

12 christine.veschambre-couture@u-bordeaux.fr (C. Couture-Veschambre)

13 lefort.anthony@sfr.fr (A. Lefort)

14 stephane.rottier@u-bordeaux.fr (S. Rottier)

15 marie-france.deguilloux@u-bordeaux.fr (M.-F. Deguilloux)

Key words:

Late Iron Age; ancient DNA; social dynamics; phylogeography; French territory

\section{Highlights:}

- Multidisciplinary study of Late Iron age groups from Northern France

- Population-scale DNA-based approach permitted the documentation of communities' internal social dynamics

- Gallic groups were characterised by patrilocal residence and patrilinearity rules

- Distinct necropolis welcomed distinct biological and social groups 

issues

26 
Abstract:

Ancient DNA (aDNA) research can address anthropological questions at both the broad continental scale to provide elements of discussion regarding ancient human population dynamics and the very small spatial scale to document population social functioning. In the present study, we propose an original approach combining local- and broad-scale issues, applied to two contemporaneous groups dated from the Late Iron Age period and originating from Northern France. Our analyses targeted uniparental markers (mitochondrial DNA (mtDNA) and the $\mathrm{Y}$ chromosome) and permitted the characterization of 43 maternal and 17 paternal lineages for the Urville-Nacqueville necropolis (UN) as well as 27 maternal and 19 paternal lineages for the Gurgy 'Les Noisats' (GLN) tumulus. Data in hand provided a unique opportunity to document Gallic communities' genetic diversities and discuss their internal social dynamics as well as their genetic affinities with other ancient European groups. At the local scale, our study first highlighted patrilocal residence rules and patrilinearity for these Gallic groups, in concordance with textual sources and archaeological data. Second, the gene pool characterization indicated that the UN necropolis welcomed a more cosmopolitan community than did the GLN tumulus and that the funerary space organization in the UN was correlated to the genetic structuration of the community. These local scale characteristics were put into perspective for broad-scale discussions and highlighted different genetic affinities of the UN and GLN communities with ancient European groups. Both communities appeared inserted in distinct exchange networks that may have been responsible for the slight differentiation of their maternal gene pools. Finally, we demonstrated that the sub-groups encountered in the UN necropolis (maternally differentiated) presented very distinct genetic affinities with ancient or contemporaneous human groups from other Western European regions. Consequently, our study reinforces the idea that the identification of genetically differentiated groups within archaeological sites and discussion concerning their specific composition constitute a clear prerequisite before addressing broad-scale phylogeographical issues. 


\section{Introduction}

Over the past decade, ancient DNA (aDNA) research has addressed archaeological and anthropological questions, whether at the broad continental scale or at the very small spatial scale. The first continental scale has provided major elements of discussion regarding ancient human population migrations, admixture or replacements (for a recent review see Harris, 2017). At the very local scale, the palaeogenetic approach has shed light on specific populations' social functioning, with an emphasis on kinships and matrimonial systems (see for example Keyser-Tracqui et al., 2003 and Haak et al., 2008). The genetic constitution of human populations can be very complex due to social structuration, specific matrimonial or filiation systems. The considerable variability of population gene pools, due to these specific internal social dynamics, implies that the use of a small number of samples to represent largely dispersed archaeological cultures may lead to erroneous interpretation of data. Moreover, the genetically analysed ancient human communities generally originate from specific funerary sites whose access may have been limited to a peculiar group who may not be fully representative of the community. Therefore, considerable variability in the genetic diversity of ancient groups can even be encountered within cemeteries. The precise understanding of both the funerary site functioning and the constitution of the "dead community", addressed through archaeological, anthropological and small-scale aDNA studies, thus constitutes a preliminary process necessary to the appropriate use of the group gene pools for the reconstruction of broad-scale population dynamics (Johannsen et al., 2017; Veeramah, 2018).

Thus far, aDNA studies addressing both scales and thus combining local communities' social functioning and phylogeographical issues remain rare (Beau et al., 2017; Knipper et al., 2017; Rivollat et al., 2015; Veeramah, 2018). For the Iron Age, our period of interest, an original study combined biological (osteology, isotopes, DNA) and archaeological data obtained on individuals from a "princely site" in Germany to investigate the social structuration of the local community (Knipper et 
al., 2014). While the data obtained allowed to discuss individuals' maternal relationships, the small gene pool recovered could not be used to address phylogeographical issues. In the present study, we propose an original approach combining local- and broad-scale issues, applied to two groups dated from the Late Iron Age period and originating from Northern France.

Our study targeted two communities corresponding to the famous French "Gauls", according to the Classical and ancients texts, and originating from the second part of the Late Iron Age sites of UrvilleNacqueville (120- 80 BC, Manche) and Gurgy 'Les Noisats' (300-100 BC, Yonne) (Fig 1 and 2). It is important to note that the communities targeted were associated to distinct Celtic Gallic cultures according to texts and historical data: Urville-Nacqueville was associated to the Unelles group whereas Gurgy "Les Noisats" was located in Senons' territory.

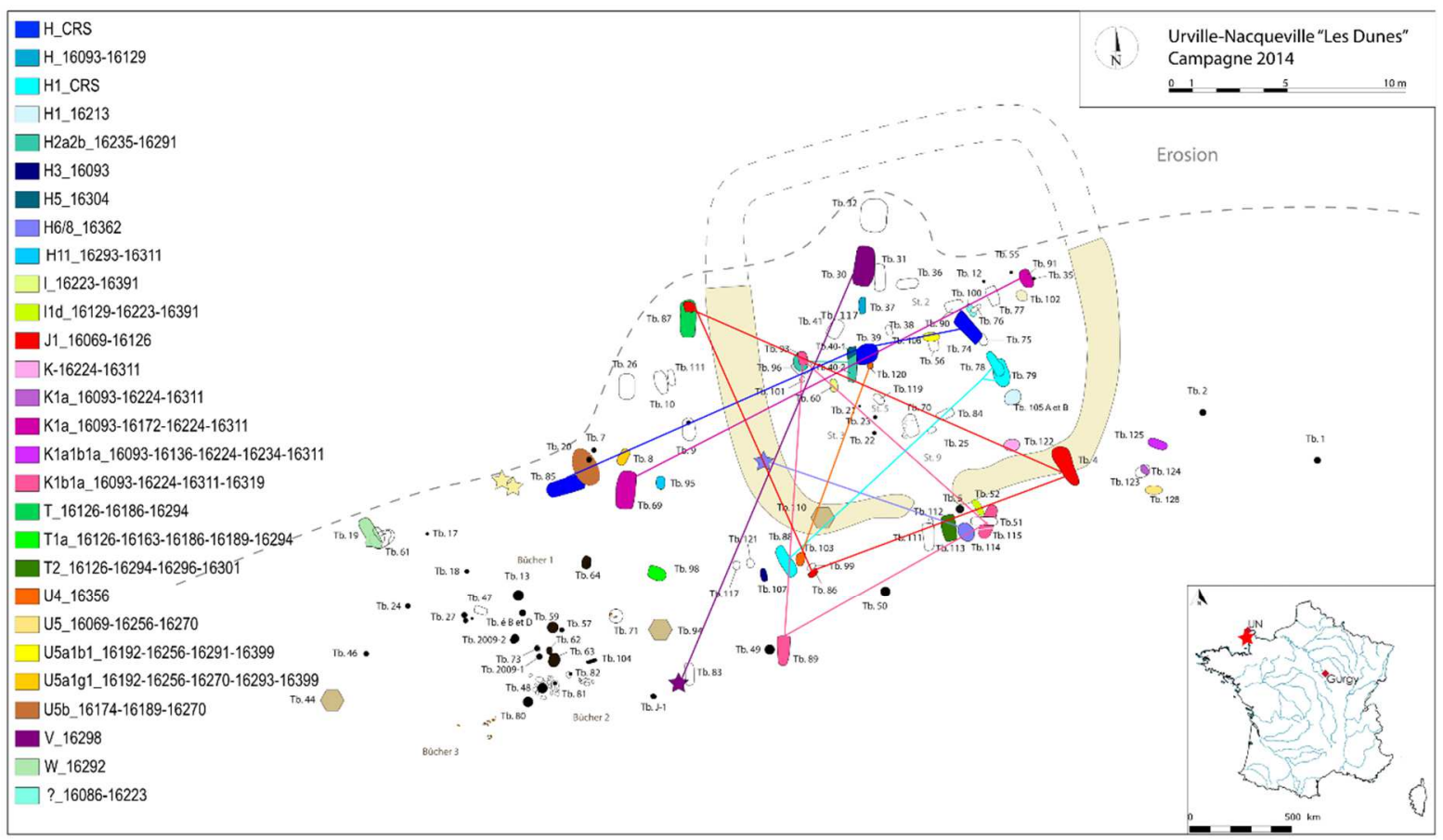

Figure 1 : Location of the Urville-Nacqueville site and spatial distribution of the mitochondrial 


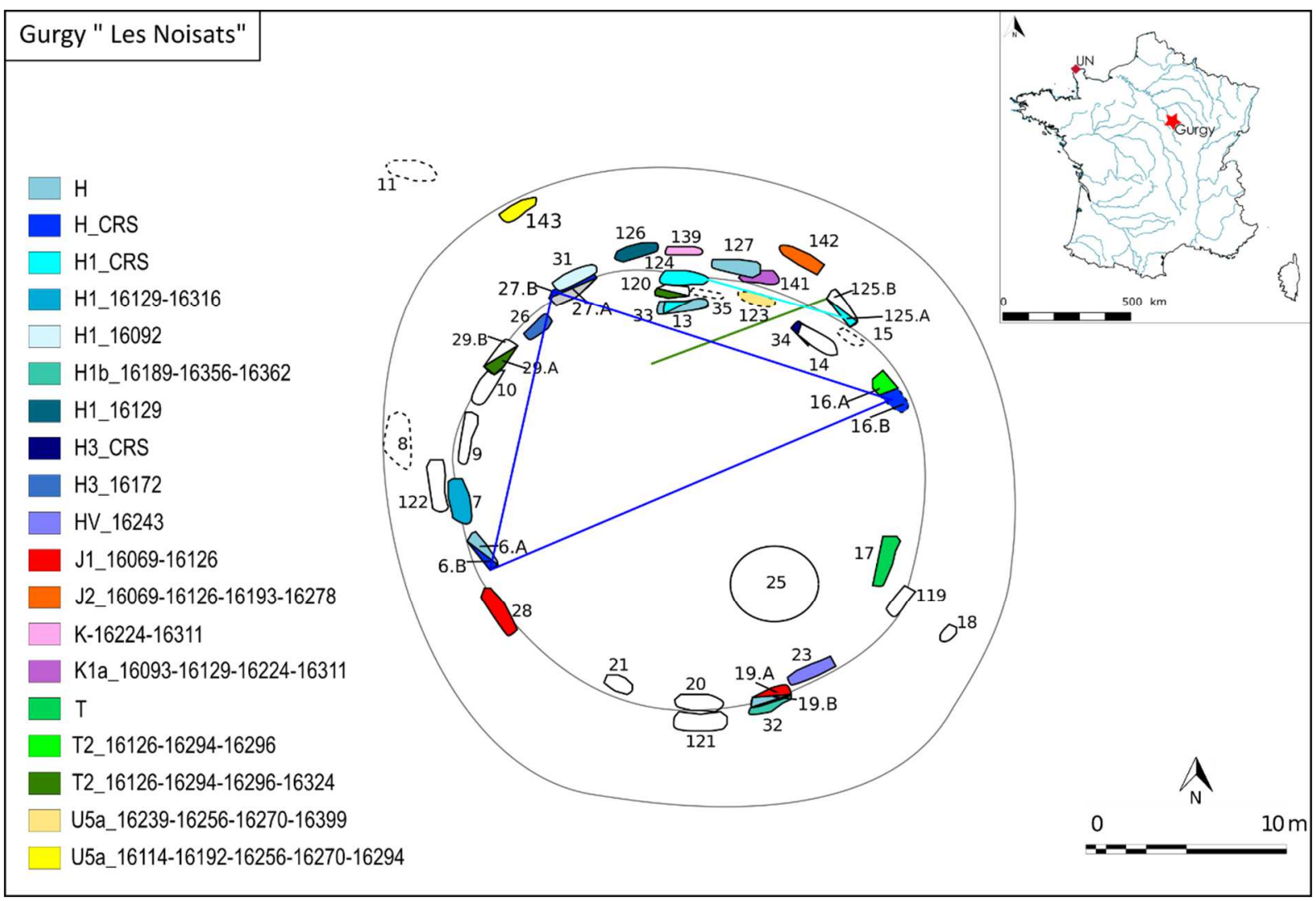

Figure 2 : Location of the Gurgy 'Les Noisats' site and spatial distribution of the mitochondrial

(mtDNA). Individuals sharing a mtDNA haplotype are linked by a line.

94

Urville-Nacqueville (UN) is a port site located along the Channel seashore which is characterized by the presence of an artisanal sector and a vast cemetery (Lefort et al., 2015). The funerary space, organized around a square enclosure, included 112 identified burials and at least 120 individuals. The necropolis of Gurgy Les Noisats is located in the Parisian Basin within the Senon's territory. Many archaeological sites dated to the Iron Age have been described in the region (Baray, 2016; Duval, 1976; Hure, 1931). Although numerous habitats could be identified in the region for the period, non could be associated to the Gurgy necropolis (Delor, 2013). Gurgy 'Les Noisats' (GLN) consists of a tumulus approximately 30 metres in diameter that received 40 individuals spread over 35 graves (unpublished). To document the biological diversity of the UN and GLN groups, our aDNA study targeted uniparental genetic markers (mitochondrial DNA, mtDNA and the Y chromosome), permitting the characterization of maternal and paternal lineages. At the very local scale, special 
attention was paid to the combination of archaeological, anthropological and genetic data (i) to discuss funerary groups' diversity and constitution, (ii) to test for the potential presence of groups genetically differentiated within each necropolis and (iii) to address each community-specific social functioning. The comparison of the results obtained for the partially contemporary sites of UN and GLN permitted us to question potential general social dynamics for the French Late Iron Age context. Interestingly, the European Iron Age is the most ancient archaeological period for which textual documentation is available. The textual sources describing the Gauls and their social habits were not written by the Gauls themselves but by contemporary Romans and Greeks and must consequently provide a distorted view of the French Iron Age groups' cultural diversity or habits. Whatever the case, texts such as the writings of Strabon, Poseidonios d'Apamée or Caesar (De Bello Gallico) have survived over time and constitute a unique opportunity to combine archaeological, biological and textual data to better understand Gallic societies. Finally, the elements of discussion obtained at the local scale were put into perspective to address broad scale issues, including (i) the biological affinities of distinct Gaul communities and (ii) the genetic legacy and dynamics of European Iron Age populations.

\section{Materials and methods}

\subsection{Archaeological samples}

The excavations of the Urville-Nacqueville necropolis permitted the discovery of 112 graves (78 burials and 34 cremations) containing the remains of at least 127 individuals (of which 41 were cremated) (Lefort and Rottier, 2014). All aDNA analyses were conducted on individuals recovered from burials (i.e., not cremated) and targeted 51 individuals distributed throughout the entire necropolis. The sample included all individuals published in Fischer et al. (Fischer et al., 2018) plus 6 newly analysed individuals (S1 Table). To obtain a clear picture of the genetic diversity of sub-groups corresponding to distinct necropolis sectors or funerary practices, we targeted individuals from both outside $(\mathrm{N}=19)$ and inside the enclosure $(\mathrm{N}=32)$, as well as several individuals from the same small 
groups of burials. The sample was thus supposed to addressing the genetic variability of intra- and extra-enclosure groups and to test for potential groupings of individuals according to maternal or paternal kinship. and to question the presence of groups genetically differentiated within each necropolis.

Contrary to the Urville-Nacqueville necropolis, which is outstanding for the period and the region, the Gurgy 'Les Noisats' (GLN) site is typical of the necropolises known for the Paris Basin during the Late Iron Age. This site corresponds to a tumulus that grouped a total of 35 graves, containing the remains of at least 40 individuals. Among the graves discovered, 8 correspond to plural tombs, and 5 of them group an adult and an immature. The limited number of individuals allowed to submit all of them to palaeogenetic analyses (S2 Table). The diameter of the tumulus (approximately $30 \mathrm{~m}$ ) as well as the absence of selection of the deceased according to age or sex or the majority of burials over cremation appeared consistent with necropolises observed for the same context (Baray, 2003; Marion et al., 2009). The combination of these characteristics with a short duration of use of the tumulus (200 years, based on metallic material, unpublished) allowed us to assume that the population recovered in the GLN tumulus was representative of the whole local community.

Since both necropolises were used during a short period (less than two hundred years) and because biological studies conducted on both sites have shown the absence of selection of the dead according to age or sex, we expect that the funerary groups were representative of the local communities as a whole. For the specific case of the UN, a change in the funerary treatment could be highlighted as related to age at death since children were usually buried while adults were burnt (Lefort and Rottier, 2014). If burnt adults were not accessible for our aDNA study, the absence of age or sex selection of individuals having access to the necropolis suggests that the gene pool recovered for the buried children group may reflect the population gene pool. Consequently, we consider that the sampling strategy designed in our study was adequate to unravel entire communities' gene pools 

against contaminations. Teeth were then preferentially collected for adults, whereas intact long bones were selected for immature individuals. All sampling performed after 2015 targeted petrous bones according to the recent discovery of the exceptional DNA conservation in this anatomical element (Pinhasi et al., 2015). The GLN human remains were collected for genetic analyses in 2016, 12 years after the excavations (unpublished). We targeted for all GLN individuals, in order of preference, petrous bones then teeth and, finally, bones. Since GLN human remains had been collected without any precautions against contamination and regularly manipulated during postexcavation studies, they were systematically decontaminated before extraction i.e., scraped, cleaned with bleach and subsequently exposed to UV radiation for 20 minutes for each side. maternal (mitochondrial DNA, mtDNA) and paternal lineages (Y-chromosome). Our approach combined the analysis of $18 \mathrm{mtDNA}$ and $10 \mathrm{Y}$-chromosome SNPs (single nucleotide polymorphisms) and the sequencing of the mtDNA Hyper Variable Sequence (HVS-1). Details of all analyses can be found in Rivollat et al. (2015). Y-chromosome SNP analyses were conducted on adult individuals identified as males through osteological analyses (determined by the Bruzek (Bruzek, 2002) and DSP (Murail et al., 2005) methods) as well as adults with undetermined sex and all immature individuals. The genetic diversities of the GLN and UN groups were measured through the computation of Nei genetic diversity $\left(\mathrm{h}^{2}\right)$ using Arlequin software (version 3.5.1.2) (Excoffier and Lischer, 2010).

177 Fisher's exact tests were used to test the statistical significance of genetic diversity differences measured between groups or DNA conservation variability observed between sites. The tests were 179 performed with BiostaTGV (https://biostatgv.sentiweb.fr/?module=tests/fisher). Resampling analyses were performed with R 3.6.0 (R Core Team, 2019) taking into account sample size 
Adjusted bootstrap confidence interval (Zieffler, Harring, \& Long, 2011) were computed for the differences in Nei's indices between the groups under study, using 10000 bootstrap replicates.

To discuss the genetic affinities of UN and GLN communities with ancient European human groups, we ran a series of descriptive analyses using the datas published by Fischer and colleagues, which includes 1433 mitochondrial sequences dating from the Palaeolithic to the Iron Age $(42,500$ 300 cal. BC), divided into 29 chronological, geographical and cultural groups (Fischer et al., 2018) (S3 Table). The proportions of shared mtDNA haplotypes and population-specific pairwise genetic distances (FST) were computed using Arlequin software (version 3.5.1.2)(Excoffier and Lischer, 2010). A principal component analysis (PCA) based on mtDNA haplogroup frequencies was carried out, taking into account the major European haplogroups identified and distinguished in aDNA literature targeting European populations: $\mathrm{H}, \mathrm{HV}, \mathrm{I}, \mathrm{J}, \mathrm{K}, \mathrm{N}, \mathrm{T}, \mathrm{U} 4, \mathrm{U} 5 \mathrm{a}, \mathrm{U} 5 \mathrm{~b}, \mathrm{U}, \mathrm{V}, \mathrm{W}, \mathrm{X}$ and "others". The PCA was performed using the R package FactoMineR (Lê et al., 2008).

\section{Results and Discussion}

\subsection{DNA conservation variability among necropolises}

Mitochondrial lineages reported for the UN site combined those already published in Fischer et al. (2018) and updated (some SNP profiles and HVS-I sequences could be completed), plus those obtained on 6 newly analysed individuals. In the end, 42 mitochondrial haplogroups (determined through SNP analysis) could be characterized over 51 targeted individuals ( $80.7 \%$ success rate), and 43 complete and authenticated HVS-1 sequences (mtDNA haplotypes) could be obtained (82.7\% success rate) (S1 and S4a Tables). Concerning the Y chromosome, 17 partial or complete SNP profiles were obtained, permitting us to corroborate the sex of 3 adults identified as males through osteological analyses and to unravel the existence of male individuals in the immature group $(\mathrm{N}=15)$ (see details in S4b Table). The analyses conducted on the 40 individuals originating from the GLN necropolis permitted the characterization of 27 mitochondrial haplogroups (67.5\% success rate) and 
23 complete HVS-1 sequences (57.5\% success rate). A total of 19 Y-chromosome SNP profiles, complete or partial, were obtained and confirmed the morphological sex of 6 male adults and provided new clues for males identification for 11 individuals (see details in S1, S4c and S4d Table). A higher success rate of HVS-1 sequence recovery could be observed for UN individuals when compared to GLN individuals (UN: $82.7 \%$; GLN:57.5\%, statistically significant; $p$ value $=0.00846$ ). The excellent conservation of mitochondrial DNA has already been highlighted for the UN necropolis (Fischer et al., 2018) and could be explained by its location on the edge of the Channel foreshore. Moreover, immature UN individuals were regularly discovered in benches made of plants, confirming the very exceptional conservation parameters in UN. Moreover, this organic material appears to have been responsible for the formation of a crust on the bones that may have protected them from various degradations.

Since our sampling targeted petrous bones, teeth and other bones, we tested for differential mitochondrial DNA conservation among these anatomical elements (S1. Figure). Fisher's exact tests revealed significant mtDNA conservation differences among anatomical elements for UN samples, with an easier mtDNA recovery for the teeth compared to other skeletal elements ( $p$ value $=0.045$ ). This result is consistent with the recent report of a higher mtDNA/nuclear DNA ratio for teeth compared to petrous bones (Furtwängler et al., 2018). Given the lower number of samples, especially for bones $(\mathrm{N}=2)$, we did not perform statistical tests to compare GLN samples. No significant differences in mtDNA recovery could be highlighted between teeth and bones (other than petrous bones), even after merging the UN and GLN results to increase the number of samples. Finally, contrary to that for teeth and bones, we observed a similar mtDNA recovery from GLN and UN petrous bones, whereas the taphonomic environments were very different. This point is in line with studies that demonstrated that DNA was less subject to environmental variations within petrous bones (Gamba et al., 2014; Hansen et al., 2017).

Finally, when samples from both sites were merged to increase sample size, mitochondrial DNA appeared to be more preserved for adults than immature individuals. Even if the difference was not 
significant $(p$ value $=0.478)$, this observation could be explained by skeletal conservation variation related to age at death. Indeed, it has been clearly shown that the anatomical conservation index (ICA) of immature individuals was lower than that measured for adults, highlighting differential macroscopic conservation according to age at death (Bello et al., 2002).

\subsection{French Iron Age communities' internal social dynamics}

A noticeable variety of mtDNA haplogroups could be characterized for the UN group (N individuals = 43), including $\mathrm{K} 1, \mathrm{~J} 1, \mathrm{H}, \mathrm{H} 1, \mathrm{H} 2, \mathrm{H} 3, \mathrm{H} 5, \mathrm{H} 6 / 8, \mathrm{H} 11, \mathrm{U} 4, \mathrm{U} 5 \mathrm{a}, \mathrm{U} 5 \mathrm{~b}, \mathrm{I}, \mathrm{V}, \mathrm{T} 1$ and T2 major lineages (Fig 1). A total of 16 sub-haplogroups and 27 distinct haplotypes could be determined among the UN sample. Among the mtDNA haplotypes discovered, 9 were shown to be shared between at least two distinct individuals, indicating possible maternal kinship (S1 Table). However, several of these shared maternal lineages corresponded to mtDNA haplotypes very frequent within ancient European groups, and their interpretation in terms of kinship determination may be erroneous. This is the case for H (CRS), H1 (CRS), J1 (16069-16126), U4 (163556) and V (16298) lineages shared by 2 to 3 individuals inside the necropolis. More interestingly, some individuals shared infrequent lineages that may thus be more informative in terms of maternal kinship, as this is the case for K1a (16093-16172-16224-16311), K1b1a (16093-16224-16311-16319), H2a2b (1623516291), H6/8 (16362) and H1 (16213) haplotypes carried by 2 to 3 individuals (Fig 1). It is worth noting that individuals sharing these maternal lineages were discovered both inside and outside the enclosure.

The smaller GLN group ( $\mathrm{N}$ individuals $=27$ ) is unsurprisingly characterized by a smaller number of mtDNA sub-haplogroups $(\mathrm{N}=9$ ) encompassing lineages $\mathrm{H}, \mathrm{H1}, \mathrm{H} 3, \mathrm{HV}, \mathrm{J} 1, \mathrm{~J} 2, \mathrm{~K}, \mathrm{U} 5 \mathrm{a}$ and $\mathrm{T} 2$. A total of 13 distinct haplotypes could be determined among the GLN sample, of which 3 were shown to be shared between at least 2 individuals. However, maternal lineages shared between GLN individuals all corresponded to very frequent mtDNA haplogroups (H (CRS), H1 (CRS) and T2a1b (16126-1629416296-16324) haplotypes), impeding any discussion in terms of maternal kinship (Fig 2). 
could be observed, all of them corresponding either to $R^{*}$ or R1b (M343) haplogroups. However, we

must highlight that the SNP markers used to characterize the individual paternal haplogroups were very low in number and did not permit deep exploration inside the Y-chromosome phylogeny. Furthermore, numerous artefactual alleles regularly appeared in the SNP profiles, complicating lineage determination. The paternal uniformity unravelled for French Iron Age groups is consequently in part the result of the genotyping design. Regardless of the case, we consistently found in our Iron Age samples $R^{*}$ / R1b paternal lineages that are linked to the massive migration from the steppes and dated to the Late Neolithic-to-Bronze Age transition (Haak et al., 2015). This migration was responsible for an impressive genetic turnover in the European populations, with Neolithic haplogroups being replaced by new paternal (R1a and R1b) lineages originating from the the groups' residence rules and (ii) the constitution of the populations buried in the necropolises. eastern regions (see below).

The Nei genetic diversity was calculated for each Iron Age group based on maternal markers and provided clues for high maternal diversity for both UN and GLN communities (0.969 and 0.885, respectively). A nonparametric adjusted bootstrap 95\% percentile interval was computed for this difference, yielding the range of $[-0.2377 ;-0.0026]$. This range of values indicates likely candidates for the true value of genetic diversity difference between these two groups. Since this interval does not include the null value, it provides moderate evidence for the hypothesis that there is a higher diversity in the UN group. We propose that the high maternal genetic diversities measured and the variation of diversities observed between our French Iron age communities can be explained by (i)

\subsubsection{A patrilocal matrimonial system?}

The gene pools of societies practising patrilocal residence rules are characterized by a series of specific features, including a low paternal lineage diversity (linked to low mobility of men) combined with a high maternal diversity (related to important mobility of women among groups, 
introducing new lineages in the recipient population) (Dudar et al., 2003; Oota et al., 2001). Both

features could be unravelled for UN and GLN sites and suggested that these communities practised patrilocal residence rules. It is worth noting that aDNA studies have regularly provided arguments permitting the identification of patrilocal residence rules for ancient European groups (Haak et al., 2008; Knipper et al., 2017; Lacan et al., 2011). For example, a study conducted by Knipper et al. (2017) on Bell Beaker and Early Bronze Age societies from Central Europe and based on aDNA and

291

292

293 isotopic data highlighted patrilocal residence system as well as exogamy for women. In this specific case, a high mitochondrial diversity $\left(h^{2}=0.9924\right)$ could be calculated. Because the maternal diversity calculated by Knipper et al. covered 80 individuals spread over 7 distinct archaeological sites dated between 2500 and 1700 BC (representing approximately 27 generations), we believe that the high maternal diversities measured for GLN and UN communities, composed of individuals originating from a unique site and distributed among only 7 generations (approximately 200 years) for GLN and only 3 generations (less than 100 years) for UN, constitute a clear argument for patrilocality.

For both UN and GLN necropolises, even if some individuals shared the same mitochondrial lineages, no group of tombs related to maternal lines could be detected (Fig 1 and 2). The absence of visible structuration of the funerary spaces according to maternal affinities may provide argument in favour of patrilinearity. In that case, the paternal homogeneity characterized inside both necropolises may be consistent with a structuration of the necropolises in link with paternal kinships. If it is obvious that more precise genomic data are necessary to confirm this hypothesis, it is nevertheless interesting to note that patrilocality and patrilinearity have both been proposed for Gaulish societies according to textual and archaeological data. In that respect, ancient texts, such as De Bello Gallico or Strabon's writings have provided arguments to consider that Gallic societies had practised patrilocal residence rules, with inter-ethnic alliances linked to the exchange of women between civitas (the civitas being a political entity that included several pagi, i.e., group of tribes with a specific ethnic identity; Lewuillon, 1990). In the same way, according to the work of Lewuillon (1990), Gallic societies may have been built on the fundamental and dominant principle of 
patrilinearity, with a very strong impact of paternal heredity on communities' internal social

structuration. Palaeogenetic data obtained for Late Iron Age UN and GLN communities are thus in

313 line with archaeological or textual arguments. Since the UN group revealed a maternal diversity statistically higher than the one measured for the GLN group, we confronted at the very local scale funerary and genetic traits available to discuss the constitution of each "dead community".

\subsubsection{Different funerary groups' constitution?}

Numerous arguments have permitted the identification of the UN site as an important place of exchange with Southern England. Indeed, the site is located along the Channel coast and faces two port sites of Southern England: Hengistbury Head and Poole Harbour. Exchanges with this region are mirrored by the presence in the UN of cultural elements shared on the both side of the Channel. This is notably the case for circular buildings, the use of lignite as a raw material for the manufacture of bracelets or the position of some buried adults, which evokes the one encountered among the Durotriges group (a contemporary group based in Dorset; Lefort et al., 2015). Obviously, the interpretation of the UN site as a place of human circulation and gene flow along the Channel and the Atlantic coast (as already discussed in Fischer et al., 2018), could explain the higher maternal diversity measured for the community.

Since the UN funerary space was clearly organized in different sectors (inside and outside an enclosure), we explored whether this funerary space organization was linked to any genetic differentiation. The observed maternal diversity $\left(h^{2}\right)$ was found to be higher for the group discovered outside the enclosure (0.983) than for the group buried inside the enclosure (0.976). This might suggest that the enclosure constituted a funerary sector that welcomed a special group of deceased. Given the relatively small sample sizes (respectively $\mathrm{N}=19$ inside and $\mathrm{N}=32$ outside the enclosure), the adjusted bootstrap confidence interval, including the null value as a credible candidate for the difference in genetic diversity between these two groups, failed to provide a strong evidence in favor 
$\mathrm{J1}$ and T) from the enclosure group (Fig 1). Consequently, we can propose the hypothesis that the enclosure was dedicated to a specific group of the community, characterized by lower genetic diversity. This hypothesis resonates with the propositions offered by archaeological studies. In some necropolises dated to the Late Iron Age, the presence of an enclosure was attributed to the appropriation of the territory by a dominant family, who gathered its deceased members in a dedicated funerary space. The structuration of the funerary space would then reflect the social hierarchy of the community members (Lambot, 2000; Verger, 2009). In the specific case of the UN necropolis, the enclosure may thus have received the members of a dominant family, characterized by lower genetic diversity than the rest of the community, due to its smaller effective size and/or endogamy. The fact that some individuals sharing the same maternal lineage were distributed both inside and outside the enclosure (Fig 1) seems counterintuitive with the hypothesis of a funerary space organized according to family structure. However, since textual sources suggest that social status was inherited through paternal lines (Lewuillon, 1990) and that our genetic data would be in accordance with societies practising patrilinearity, the funerary space should be rather structured alongside Y-chromosome lineages. Unfortunately, our low-resolution analysis of paternal lineages does not permit us to test this point. An alternative hypothesis concerning the constitution of the dead groups having access to the different UN sectors may include chronological evolution from an initial group. Indeed, some archaeological arguments may indicate that the enclosure was used before the rest of the necropolis. Notably, individuals UN-4 and UN-108 were found in graves dug across the enclosure ditch and must therefore have been buried after the enclosure disappearance. This could indicate that the enclosure and the individuals buried in it were more ancient than the individuals found outside. In such a case, the older funerary group found in the enclosure could have corresponded to a smaller funding group (with a lower diversity), which may have been at the origin

361 of a larger community found outside the enclosure or have been replaced by this more recent group.

362 Nevertheless, the chronological succession of genetically differentiated groups must have occurred 
over only a hundred years i.e., the duration of use of the UN necropolis. Whatever the case, if the processes implied in the genetic differentiation of the groups found inside vs. outside the enclosure in Urville-Nacqueville remain to be determined, the presence in the site of two genetically differentiated groups must be taken into account when addressing broad scale issues including groups' biological affinities, genetic legacies and dynamics.

As already mentioned, the combination of these characteristics with a short duration of use of the tumulus (200 years) allowed us to assume that the population recovered in the GLN tumulus was representative of the whole local community. The lower maternal genetic diversity measured for the GLN group could be explained by the fact that the necropolis welcomed the members of a more local community than the cosmopolitan population found in the UN site. According to Gerritsen (Gerritsen, 2006, 2003), a local community includes people who interact daily in a reduced social context in space, such as hamlets or a group of farms, and who can share a common burial place and could therefore be considered a group of affiliated individuals. For other authors, the extended family group is a unit of production, consumption and social interaction in which people participate in collective decisions and defend their own interests and those of their members (Fernández-Götz, 2014). For our study, we preferred to use the term local community in the sense defined by Gerritsen.

Interestingly, several studies have permitted a better understanding of the local organization of Gaul societies. Notably, Brun's work has permitted to show that, in a rural context, territories were organized into isolated farms distributed every 3 to $5 \mathrm{~km}$ (Brun, 2011). This spatial organization of agricultural communities appears to have been established during the second part of the Bronze Age and persisted during the Iron Age. More recent studies have estimated the number of vici and aedificia composing a civita (Lejars and Gruel, 2015; Verger, 2009). These terms refer to various political, spatial and social entities proposed for the Gallic communities. Thus, a civitas was a political entity that included several pagi, i.e., groups of tribes characterized by specific ethnic identities. Civitas were composed of vici grouping themselves within several aedificia (Fernández-Götz, 2014). 
The aedificia corresponded to both the farm buildings and their inhabitants and could be compared to what Fernandez-Götz called "households" (Fernández-Götz, 2014). For some authors, these households represent the "locus of everyday life and producer of most of the activities and things that archaeologists recover" (Earle and Kristiansen, 2010) and must therefore be distinguished from the nuclear family concept. In this special context, different theoretical types of tomb and habitat configurations have been proposed (Brun, 2011). Among them, the model "grouped tombs and dispersed habitat", i.e., a common funerary site used for several households scattered around the necropolis could correspond to what we found in GLN. While no habitat area is currently known and associated with the GLN tumulus, the moderate number of burials and the lower mitochondrial diversity observed prompt us to propose the hypothesis of the use of the tumulus by a local community distributed among few aedificia.

The data available for UN and GLN necropolises thus indicated (i) that they welcomed different types of communities (more cosmopolitan for UN vs. more local for GLN) and (ii) that the structuration of the funerary space in UN was linked to a genetic structuration of the community. Consequently, it is necessary to take into account these specificities for the reconstruction of broad-scale population dynamics.

\subsection{French Iron Age communities' affinities and dynamics}

\subsubsection{A common maternal legacy but distinct exchange networks}

We first conducted descriptive analyses taking into account the gene pools of whole UN and GLN groups. A principal component analysis (PCA) based on mtDNA haplogroup frequencies was computed after the merging of the UN and GLN gene pools with those of available ancient groups dated from the Palaeolithic to the Iron Age (database published in Fischer et al. 2018). Since potential maternal kinship within both UN and GLN necropolises has been previously noted (which may bias haplogroup frequency estimations), we carried out PCA either considering all the 
414 individuals (Fig 3) or only one individual per haplotype (S2 Fig). As the exclusion of potentially 415 maternally related individuals had no significant effect on the PCA structure, we decided in the main 416 text to present the PCA obtained for the entire UN and GLN groups. 

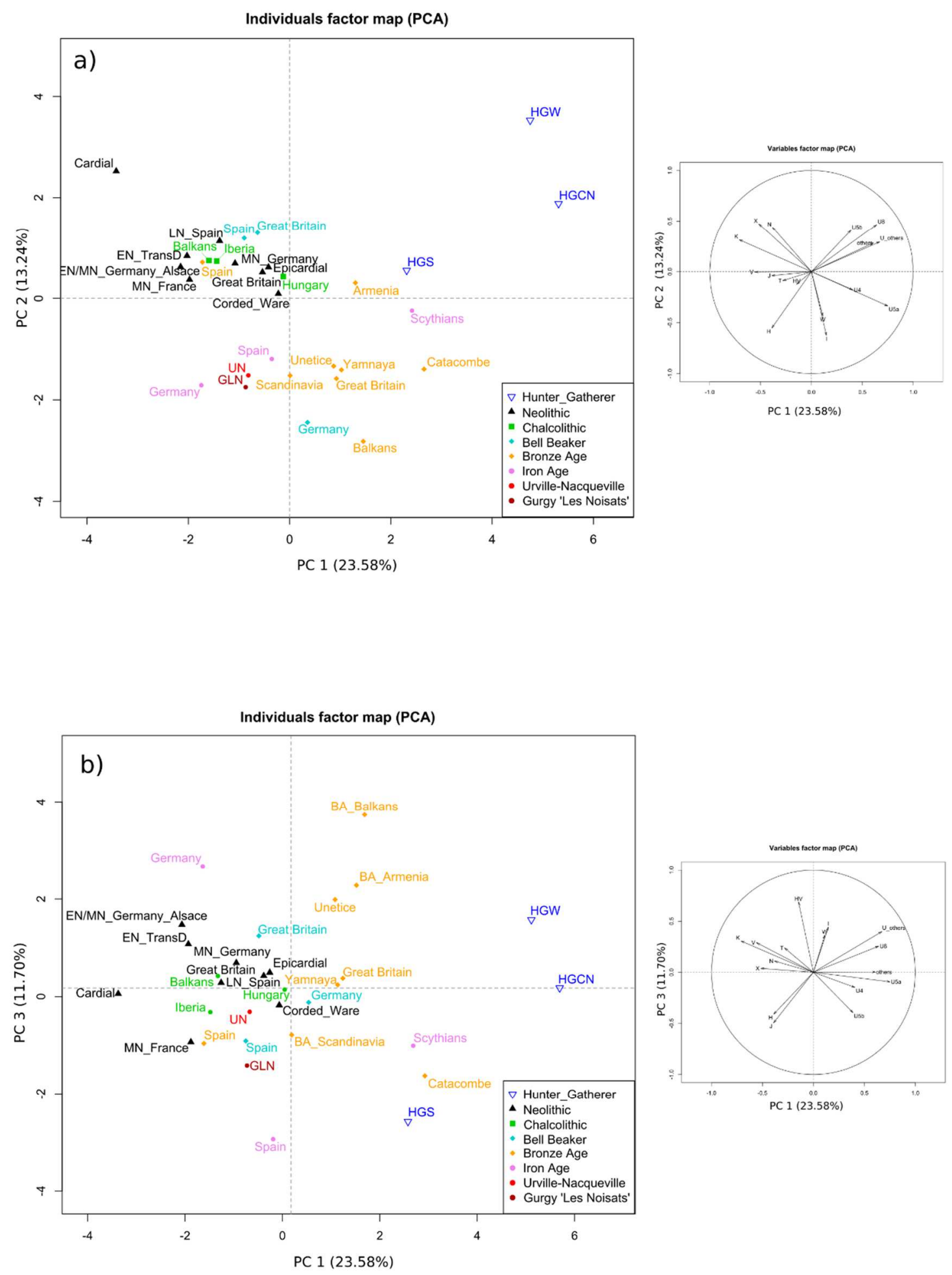

Noisats'. most of the variations in mtDNA haplogroup frequencies lies between ancient European huntergatherers, Neolithic and Bronze Age groups. In this PCA, the UN and GLN samples grouped with other Iron Age groups from Spain and Germany, and this western European Iron Age cluster showed clear affinities with Bronze Age groups, indicating global maternal continuity between groups from both periods. The first important outcome of our analyses was then the demonstration of a coherent western European Iron Age group (composed of populations from Germany, France and Spain), notably characterized by a high proportion of haplogroup $\mathrm{H}(\mathrm{UN}=38.63 \%, \mathrm{GLN}=58.6 \%$, IA_Spain $=$ $37.5 \%$ and IA_Germany $=36.36 \%)($ S6 Table). Such proportions of haplogroup $\mathrm{H}$ are close to the values observed for current European populations. Since it has been demonstrated that the major genetic ancestral components of current European populations were introduced during the Bronze Age (Allentoft et al., 2015; Haak et al., 2015), the resemblance between Iron Age groups and extant European populations was expected. The second important outcome of our analyses was directly linked to the previous one and corresponded to the characterization of a clear maternal steppe legacy in both UN and GLN communities. Distinct lines of evidence supported this point. First, the UN and GLN position in the PCA appeared linked to high frequencies of maternal lineage $\mathrm{H}$ and a noticeable proportion of haplogroups U4 (for UN group) and I, three characteristics shared with

442 European Bronze Age groups bearing an important steppe legacy (S6 Table). Second, clear affinities 443 between our French Late Iron Age communities and Yamnaya pastoralist groups or groups 444 presenting a major steppe-ancestry component (i.e., groups linked to Corded Ware Culture (CWC), 445 groups associated with Bell Beaker in Germany (BBC_GER), Great Britain (BBC_GB) or Spain 

supported through (i) the study of shared informative haplotype frequencies (S7 Table) or (ii) the measurement of close genetic distances (FST; S8 Table). Lastly, the partial data obtained for Ychromosome lineages in UN and GLN revealed a striking majority of haplogroups $R^{*} / R 1 b$ that were mainly associated with the arrival of steppe migrants in central Europe after 3000 BC (Allentoft et al., 2015; Haak et al., 2015; Mathieson et al., 2015). some divergences in terms of genetic affinities with distinct regional ancient groups. The second PCA, computed with PC1 and PC3 (respectively $23.58 \%$ and $11.70 \%$ ) (Fig $3 \mathrm{~b}$ ), tended to associate groups dated from the Neolithic to the Iron Age, found within each European region. In this PCA, it is worth noting that the GLN group held a specific position close to the Middle Neolithic group from the same location (MN_France; Rivollat et al., 2015) and to ancient groups from Spain associated with Bell Beaker culture or dated to the Early Bronze Age. The maternal affinities between GLN and ancient groups from Spain were also supported by low FST values (all in the range of 0.02; S8 Table) as well as noticeable shared haplotype rates with the Spanish group associated with the Epicardial (6.67\%) or dated to the Bronze Age (6.67\%) (S7 Table). If similar maternal affinities could be identified between the UN group and groups from Spain (through the study of both shared informative haplotype frequencies (S7 Table) or genetic distances (S8 Table)), they were always found in combination with affinities with groups from Great Britain, associated with Bell Beaker culture or dated to the Early Bronze Age. For the UN group, these maternal links with Great Britain and Spain may be explained by genetic exchanges along the Atlantic coast either during the Neolithic or the Bronze Age periods (as already discussed in Fischer et al. 2018). In sum, the different geographical positions of the UN and GLN communities, inserted in distinct exchange networks, may have been responsible for the slight differentiation of their maternal gene pools and affinities. 
Because we could demonstrate that the Urville-Nacqueville funerary group was composed of two

473 maternally differentiated sub-groups (corresponding either to two socially distinct groups and/or to a

474 chronological evolution from an initial group), we tested for potential distinct maternal legacy. We consequently performed all the same descriptive analyses (PCA, FST, shared haplotypes), separating groups buried inside the enclosure ("UN_intra_enclos") vs. groups found outside the enclosure 477 ("UN_extra_enclos"). Interestingly, the results of these analyses revealed different maternal affinities depending on the group considered. Notably, we observed in PCA computed with either PC1 and PC2 (23.03\% and $13.5 \%)$ or PC1 and PC3 $(23.03 \%$ and $11.72 \%)$ that "UN_intra_enclos" and "UN_extra_enclos" groups were systematically placed in very distinct positions. In the first PCA, the group originating from the enclosure notably held a very special outlier position, whereas the group buried outside the enclosure was found to be very close to the GLN group. This first analysis may indicate a very special maternal constitution of the group having access to the UN enclosure. However, the results obtained through subsequent analyses were more difficult to interpret. Indeed, the second PCA (S3 Fig) indicated affinities between the group buried outside the enclosure and Neolithic groups of Germany, Spain and Great Britain, while the group found inside the enclosure was determined to be closer to the groups from Spain dated from the Late Neolithic or the Chalcolithic periods. The FST calculated for the distinct funerary groups also pointed out different affinities, with the group from the enclosure being closer to the Channel / Atlantic coast groups $\left(E B A \_G B=0.01625 ;\right.$ Cardial $=0.01823 ; B B C \_S p a i n=0.01848 ; C_{-}$Iberia $\left.=0.02099\right)$ while the group outside the enclosure presented more affinities with French groups from the Paris basin dated from the Neolithic and Iron Ages (MNF $=0.00865: G L N=0.01039)$ as well as with various groups from Central Europe (EN_MN_Germany_Alsace $=0.01716$; EN_transDanubia $=0.0863$ and IA_Germany $=$ 0.01963) (Table S9). Finally, affinities regarding eastern groups differentiated the two UN funerary groups. Notably, maternal affinities with the Yamnaya pastoralist groups were stronger for the group outside the enclosure in regard to the group buried inside the enclosure (FST 0.02755 and 0.04687 , 
that the group having access to a specific funerary structure in the UN necropolis, an enclosure, was characterized by a special maternal gene pool, showing affinities with ancient groups distributed along the Channel or the Atlantic region (Spain). In contrast, the group buried outside the enclosure may have resembled the typical French Gaul community found in GLN. These elements of discussion would reinforce the idea of a social structuration linked to the funerary organization found in the UN necropolis and/or support the hypothesis of a funding group, partly originating from an allochthonous region, establishing the necropolis and having access to the enclosure. Then, this group may have opened this matrimonial system and this funerary space to some populations, which are more similar to the one observed at GLN. Although these hypotheses need to be tested through more precise palaeogenomic analyses, the results obtained highlight the fact that genetically differentiated groups can be encountered within cemeteries and that these groups may present very distinct genetic affinities with ancient or contemporaneous human groups from other regions. The identification of these genetically differentiated funerary groups and discussions concerning their specific composition constitute a clear prerequisite before addressing broad-scale phylogeographical issues.

\section{Conclusion}

The ancient DNA results obtained for two human groups of the French Late Iron Age are in total accordance with textual sources or archaeological data describing both paternal residence rules and patrilinearity for Gaulish societies. Beyond these common internal social dynamics, the comparison of genetic, osteological and archaeological data permitted us to note that the necropolises analysed welcomed communities with distinct compositions. Indeed, the Urville-Nacqueville necropolis, located along the Channel seashore and linked to a port, appeared to host a more cosmopolitan community than the Gurgy 'Les Noisats' tumulus that may have received the deceased of a local community. Moreover, the fine-scale analysis of both communities revealed that the organization of the funerary space in the UN necropolis was directly linked to a genetic structuration of the funerary 

accession numbers MH051192 - MH051228 and MK612040 - MK612073).

\section{Conflicts of interest}

The authors declare that they have no conflicts of interest.

\section{Acknowledgments} greatly improved the manuscript.

\section{Data Availability Statement:}

group. Indeed, data in hand permitted us to propose that the enclosure discovered in this site may have either received the members of a dominant family or a smaller funding group that may have been at the origin of a larger community found outside the enclosure. Finally, we demonstrated that genetically differentiated groups found within the UN necropolis presented very distinctive signals concerning genetic affinities with contemporary or more ancient groups. These results highlight how fine-scale analyses of ancient groups permit a better understanding of community establishment or internal social functioning necessary for a correct assessment of broad-scale genetic affinities.

We would like to warmly thank R. Petit and the Pierroton Genome Transcriptome team for their comments and assistance. We would also like to thank G. Depierre as well as the members of the Université de Bourgogne and the UMR 6298 ArTeHiS for their hospitality during the sampling of the Gurgy 'Les Noisats' collection. We also acknowledge everyone who contributed to excavations at UN and GLN. . We finally thank anonymous reviewers for helpful and constructive comments which

The sequences were deposited in the GenBank database (http://www.ncbi.nlm.nih.gov/genbank/;

\section{$544 \quad$ Funding sources}


545 This study benefitted from excavation grant support from the Ministère de la Culture et de la

546 Communication, the Service Régional de I'Archéologie de Basse-Normandie (number OA2033 and

547 OA3123) and DRASM (Direction of submarine archaeological research), and from Department of

548 Manche, as well as the Service Régional de l'Archéologie de Bourgogne (site number 89198 008).

549 This research was funded by a ministerial grant from the Research National Agency as part of the

550 ANR-10-LABX-52 (http://www.agence-nationale-recherche.fr/) (Identi-Fer project, S. Rottier Dir,

551 2018-2020). The study was also financially supported by a PhD research grant from the Ministère de

552 I'Enseignement Supérieur et de la Recherche for CEF (http://www.enseignementsup-

553 recherche.gouv.fr/). Part of the experiments presented (SNPs analyses) were performed at the

554 Genomic and Sequencing Facility of Bordeaux, grants from the Conseil Régional d'Aquitaine

$555 n^{\circ} 20030304002 F A$ and 20040305003FA, https://www.nouvelle-aquitaine.fr/, from the European

556 Union, FEDER n²003227 and from Investissements d'avenir, Convention attributive d'aide NªNR-

557 10-EQPX-16-01, http://www.agence-nationale-recherche.fr/. The funders had no role in study

558 design, data collection and analysis, decision to publish, or preparation of the manuscript.

559 
561

562

563

564

565

566

567

568

569

570

571

572

573

574

575

576

577

578

579

580

581

Allentoft, M.E., Sikora, M., Sjögren, K.G., Rasmussen, S., Rasmussen, M., Stenderup, J., Damgaard, P.B., Schroeder, H., Ahlström, T., Vinner, L., Malaspinas, A.S., Margaryan, A., Higham, T., Chivall, D., Lynnerup, N., Harvig, L., Baron, J., Casa, P. Della, Dąbrowski, P., Duffy, P.R., Ebel, A. V., Epimakhov, A., Frei, K., Furmanek, M., Gralak, T., Gromov, A., Gronkiewicz, S., Grupe, G., Hajdu, T., Jarysz, R., Khartanovich, V., Khokhlov, A., Kiss, V., Kolář, J., Kriiska, A., Lasak, I., Longhi, C., McGlynn, G., Merkevicius, A., Merkyte, I., Metspalu, M., Mkrtchyan, R., Moiseyev, V., Paja, L., Pálfi, G., Pokutta, D., Pospieszny, Ł., Douglas Price, T., Saag, L., Sablin, M., Shishlina, N., Smrčka, V., Soenov, V.I., Szeverényi, V., Tóth, G., Trifanova, S. V., Varul, L., Vicze, M., Yepiskoposyan, L., Zhitenev, V., Orlando, L., Sicheritz-Pontén, T., Brunak, S., Nielsen, R., Kristiansen, K., Willerslev, E., 2015. Population genomics of Bronze Age Eurasia. Nature 522, 167-172. https://doi.org/10.1038/nature14507

Baray, L., 2016. Les cimetières celtiques du Bassin parisien (VIlè-Ile siècle av. J.-C.). Systèmes typologique et chronologique., CNRS. ed. Gallia, Hors série, Paris.

Baray, L., 2003. Pratiques funéraires et sociétés de l'âge du Fer dans le Bassin parisien (dernier quart du VIle s. - troisième quart du Ile s. av. J.-C.)., Edition CN. ed. Paris.

Beau, A., Rivollat, M., Réveillas, H., Pemonge, M.H., Mendisco, F., Thomas, Y., Lefranc, P., Deguilloux, M.F., 2017. Multi-scale ancient DNA analyses confirm the western origin of Michelsberg farmers and document probable practices of human sacrifice. PLoS One 12, 1-16. https://doi.org/10.1371/journal.pone.0179742

Bello, S., Signoli, M., Rabino Massa, E., Dutour, O., 2002. Les processus de conservation 
Brun, P., 2011. Les territoires en Europe pendant les Âges du Bronze et du Fer, in: KourtessiPhilippakis, G., Treuil, R. (Eds.), Archéologie Du Territoire, de L’Egée Au Sahara. La Sorbonne, La Sorbonne, pp. 213-230.

Bruzek, J., 2002. A method for visual determination of sex, using the human hip bone. Am. J. Phys. Anthropol. 117, 157-168. https://doi.org/10.1002/ajpa.10012

Delor, J.-P., 2013. Carte archéologique de la Gaule 89-1 et 89-2 : L’Yonne.

Dudar, J.C., Waye, J.S., Saunders, S.R., 2003. Determination of a kinship system using ancient DNA, mortuary practice, and historic records in an upper Canadian pioneer cemetery. Int. J. Osteoarchaeol. 13, 232-246. https://doi.org/10.1002/oa.680

Duval, A., 1976. Aspects de La Tène moyenne dans le Bassin Parisien. Bull. la Société préhistorique française. Études Trav. 73, 457-484. https://doi.org/10.3406/bspf.1976.8403

Earle, T., Kristiansen, K., 2010. Introduction: Theory and Practice in the Late Prehistory of Europe, in: Earle, T., Kristiansen, K. (Eds.), Organizing Bronze Age Societies. Cambridge University Press, Cambridge, pp. 1-33.

Excoffier, L., Lischer, H.E.L., 2010. Arlequin suite ver 3.5: A new series of programs to perform population genetics analyses under Linux and Windows. Mol. Ecol. Resour. 10, 564-567. https://doi.org/10.1111/j.1755-0998.2010.02847.x

Fernández-Götz, M., 2014. Identity and Power: The Transformation of Iron Age Societies in Northeast Gaul., Amsterdam. ed. Amsterdam. 
603

604

605

606

607

608

609

610

611

612

613

614

615

616

617

618

619

620

621

622

623

624

625

Fischer, C.-E., Lefort, A., Pemonge, M.-H., Couture-Veschambre, C., Rottier, S., Deguilloux, M.-F., 2018. The multiple maternal legacy of the Late Iron Age group of UrvilleNacqueville (France, Normandy) documents a long-standing genetic contact zone in northwestern France. PLoS One 13, e0207459. https://doi.org/10.1371/journal.pone.0207459

Furtwängler, A., Reiter, E., Neumann, G.U., Siebke, I., Steuri, N., Hafner, A., Lösch, S., Anthes, N., Schuenemann, V.J., Krause, J., 2018. Ratio of mitochondrial to nuclear DNA affects contamination estimates in ancient DNA analysis. Sci. Rep. 8, 14075. https://doi.org/10.1038/s41598-018-32083-0

Gamba, C., Jones, E.R., Teasdale, M.D., McLaughlin, R.L., Gonzalez-Fortes, G., Mattiangeli, V., Domboróczki, L., Kővári, I., Pap, I., Anders, A., Whittle, A., Dani, J., Raczky, P., Higham, T.F.G., Hofreiter, M., Bradley, D.G., Pinhasi, R., 2014. Genome flux and stasis in a five millennium transect of European prehistory. Nat. Commun. 5, 5257. https://doi.org/10.1038/ncomms6257

Gerritsen, F., 2006. Archaeological perspectives on Local Communities, in: Bintliff, J.L. (John L.. (Ed.), A Companion to Archaeology. John Wiley \& Sons, Ltd, Oxford, pp. 141-145.

Gerritsen, F., 2003. Local identities. Landscape and community in the late prehistoric MeuseDemer-Scheldt region, Amsterdam. ed. Amsterdam.

Haak, W., Brandt, G., Jong, H.N. d, Meyer, C., Ganslmeier, R., Heyd, V., Hawkesworth, C., Pike, A.W.G., Meller, H., Alt, K.W., 2008. Ancient DNA, Strontium isotopes, and osteological analyses shed light on social and kinship organization of the Later Stone Age. Proc. Natl. Acad. Sci. 105, 18226-18231.

https://doi.org/10.1073/pnas.0807592105 
Haak, W., Lazaridis, I., Patterson, N., Rohland, N., Mallick, S., Llamas, B., Brandt, G., Nordenfelt, S., Harney, E., Stewardson, K., Fu, Q., Mittnik, A., Bánffy, E., Economou, C., Francken, M., Friederich, S., Pena, R.G., Hallgren, F., Khartanovich, V., Khokhlov, A., Kunst, M., Kuznetsov, P., Meller, H., Mochalov, O., Moiseyev, V., Nicklisch, N., Pichler, S.L., Risch, R., Rojo Guerra, M. a., Roth, C., Szécsényi-Nagy, A., Wahl, J., Meyer, M., Krause, J., Brown, D., Anthony, D., Cooper, A., Alt, K.W., Reich, D., 2015. Massive migration from the steppe was a source for Indo-European languages in Europe. Nature 522, 207-211. https://doi.org/10.1038/nature14317

Hansen, H.B., Damgaard, P.B., Margaryan, A., Stenderup, J., Lynnerup, N., Willerslev, E., Allentoft, M.E., 2017. Comparing Ancient DNA Preservation in Petrous Bone and Tooth Cementum. PLoS One 12, e0170940. https://doi.org/10.1371/journal.pone.0170940

Harris, E.E., 2017. Demic and cultural diffusion in prehistoric Europe in the age of ancient genomes. Evol. Anthropol. Issues, News, Rev. 26, 228-241. https://doi.org/10.1002/evan.21545

Hure, A., 1931. Le Sénonais aux âge du Bronze et du Fer. Les Senons d'après l'archéologie. Johannsen, N.N., Larson, G., Meltzer, D.J., Vander Linden, M., 2017. A composite window into human history. Science (80-. ). 356, 1118-1120. https://doi.org/10.1126/science.aan0737

Keyser-Tracqui, C., Crubézy, E., Ludes, B., 2003. Nuclear and mitochondrial DNA analysis of a 2,000-year-old necropolis in the Egyin Gol Valley of Mongolia. Am. J. Hum. Genet. 73, 247-60. https://doi.org/10.1086/377005

Knipper, C., Meyer, C., Jacobi, F., Roth, C., Fecher, M., Stephan, E., Schatz, K., Hansen, L., 
Posluschny, A., Höppner, B., Maus, M., Pare, C.F.E., Alt, K.W., 2014. Social

differentiation and land use at an Early Iron Age "princely seat": Bioarchaeological investigations at the Glauberg (Germany). J. Archaeol. Sci. 41, 818-835. https://doi.org/10.1016/j.jas.2013.09.019

Knipper, C., Mittnik, A., Massy, K., Kociumaka, C., Kucukkalipci, I., Maus, M., Wittenborn, F., Metz, S.E., Staskiewicz, A., Krause, J., Stockhammer, P.W., 2017. Female exogamy and gene pool diversification at the transition from the Final Neolithic to the Early Bronze Age in central Europe. Proc. Natl. Acad. Sci. 114, 10083-10088. https://doi.org/10.1073/pnas.1706355114

Lacan, M., Keyser, C., Ricaut, F.-X., Brucato, N., Duranthon, F., Guilaine, J., Crubézy, E., Ludes, B., 2011. Ancient DNA reveals male diffusion through the Neolithic Mediterranean route. Proc. Natl. Acad. Sci. U. S. A. 108, 9788-91. https://doi.org/10.1073/pnas.1100723108

Lambot, B., 2000. Les enclos funéraires en Champagne : indicateurs chronologiques, sociaux, culturels ? Rev. archéologique Picardie 1, 147-159. https://doi.org/10.3406/pica.2000.2234

Lê, S., Josse, J., Husson, F., 2008. FactoMineR : An R Package for Multivariate Analysis. J. Stat. Softw. 25, 1-18. https://doi.org/10.18637/jss.v025.i01

Lefort, A., Baron, A., Blondel, F., Méniel, P., Rottier, S., 2015. Artisanat, commerce et nécropole. Un port de La Tène D1 à Urville-Nacqueville, in: Olmer, F., Roure, R. (Eds.), Les Gaulois Au Fil de l'eau, Actes Du 37è Colloque International de l'Association Française Pour l'Etude de l'âge Du Fer (Montpellier, 2013). Ausonius, Bordeaux, pp. 481-514. 
Lefort, A., Rottier, S., 2014. Opération de fouilles archéologiques sur l'estran d'UrvilleNacqueville. Rapport d'opération 2014 : La nécropole de La Tène finale.

Lejars, T., Gruel, K., 2015. Peuple, civitates, pagi, in: Buchsenschutz, O. (Ed.), L’Europe Celtique à l'âge Du Fer (VIIlè - ler Siècles). Presses universitaires de France, pp. 349357.

Lewuillon, S., 1990. Affinités, parentés et territoires en Gaule indépendante : fragments d'anthropologie. Dialogues d'histoire ancienne 16, 283-358. https://doi.org/10.3406/dha.1990.1471

Marion, S., Gaultier, M., Villenave, C., Chimier, J.-P., 2009. Sépultures et ensembles funéraires du second âge du Fer en lle-de-France et en Région Centre. S. Marion, M. Gaultier, Villenave C, Chimier J.-P. et coll., in: Barral, P., Dedet, B., Delrieu, F., Giraud, P., Le Goff, I., Marion, S., Villard-Le Tiec, A. (Eds.), Gestes Funéraires En Gaule Au Second Age Du Fer. Presses Universitaires de Franche-Comté, Besançon.

Mathieson, I., Lazaridis, I., Rohland, N., Mallick, S., Patterson, N., Roodenberg, S.A., Harney, E., Stewardson, K., Fernandes, D., Novak, M., Sirak, K., Gamba, C., Jones, E.R., Llamas, B., Dryomov, S., Pickrell, J., Arsuaga, J.-L., de Castro, J.M.B., Carbonell, E., Gerritsen, F., Khokhlov, A., Kuznetsov, P., Lozano, M., Meller, H., Mochalov, O., Moiseyev, V., Guerra, M.A.R., Roodenberg, J., Vergès, J.M., Krause, J., Cooper, A., Alt, K.W., Brown, D., Anthony, D., Lalueza-Fox, C., Haak, W., Pinhasi, R., Reich, D., 2015. Genome-wide patterns of selection in 230 ancient Eurasians. Nature 528, 499-503. https://doi.org/10.1038/nature16152

Murail, P., Brůžek., J., Houët, F., Cunha, E., 2005. DSP: a tool for probabilistic sex diagnosis using worldwide variability in hip-bone measurements. Bull. Mem. Soc. Anthropol. Paris 

17, 167-176.

695

696

697

698

699

700

701

702

703

704

705

706

707

708

709

710

711

712

713

714

715

Oota, H., Settheetham-Ishida, W., Tiwawech, D., Ishida, T., Stoneking, M., 2001. Human mtDNA and Y-chromosome variation is correlated with matrilocal versus patrilocal residence. Nat. Genet. 29, 20-21. https://doi.org/10.1038/ng711

Pinhasi, R., Fernandes, D., Sirak, K., Novak, M., Connell, S., Alpaslan-Roodenberg, S., Gerritsen, F., Moiseyev, V., Gromov, A., Raczky, P., Anders, A., Pietrusewsky, M., Rollefson, G., Jovanovic, M., Trinhhoang, H., Bar-Oz, G., Oxenham, M., Matsumura, H., Hofreiter, M., 2015. Optimal ancient DNA yields from the inner ear part of the human petrous bone. PLoS One 10, 1-13. https://doi.org/10.1371/journal.pone.0129102

R Core Team, 2018. R: The R Project for Statistical Computing [WWW Document]. URL https://www.r-project.org/ (accessed 4.25.19).

Rivollat, M., Mendisco, F., Pemonge, M.H., Safi, A., Saint-Marc, D., Brémond, A., CoutureVeschambre, C., Rottier, S., Deguilloux, M.F., 2015. When the waves of European neolithization met: First paleogenetic evidence from early farmers in the Southern Paris Basin. PLoS One 10. https://doi.org/10.1371/journal.pone.0125521

Veeramah, K.R., 2018. The importance of fine-scale studies for integrating paleogenomics and archaeology. Curr. Opin. Genet. Dev. 53, 83-89.

https://doi.org/10.1016/j.gde.2018.07.007

Verger, S., 2009. Société, politique et religion en Gaule avant la Conquête. Eléments pour une étude anthropologique. Pallas 80, 61-82. 


\section{Supplementary data}

S1 Percentage of mitochondrial DNA recovery depending on sites and skeletal elements

S2 Fig. PCA taking into account potential kinship between individuals

S3 Fig. PCA considering UN as two groups

SI. Script. R-Script used for genetic diversity computation as well as resampling tests (.txt)

S1 Table. Biological and genetic data compiled for Urville-Nacqueville individuals targeted in our study. (XLSX)

S2 Table. Biological and genetic data compiled for Gurgy 'Les Noisats' individuals targeted in our study. (XLSX)

S3 Table. Details and references of the ancient populations dataset. (XLSX)

S4 Table. Details of the mtDNA and Y-chromosome SNPs analysed on Urville-Nacqueville and Gurgy 'Les Noisats' human remains. (XLSX)

S5 Table. Genetic diversity indices measured on ancient groups. (XLSX)

S6 Table. MtDNA haplogroups frequencies for ancient groups (XLSX)

S7 Table. Mitochondrial haplotypes shared between UN and GLN communities and ancient

S8 Table. Fst values measured between ancient European groups (XLSX)

S9 Table. Mitochondrial haplotypes shared between UN and GLN communities and ancient groups and Fst values measured between ancient European groups if UN is considered as two groups 


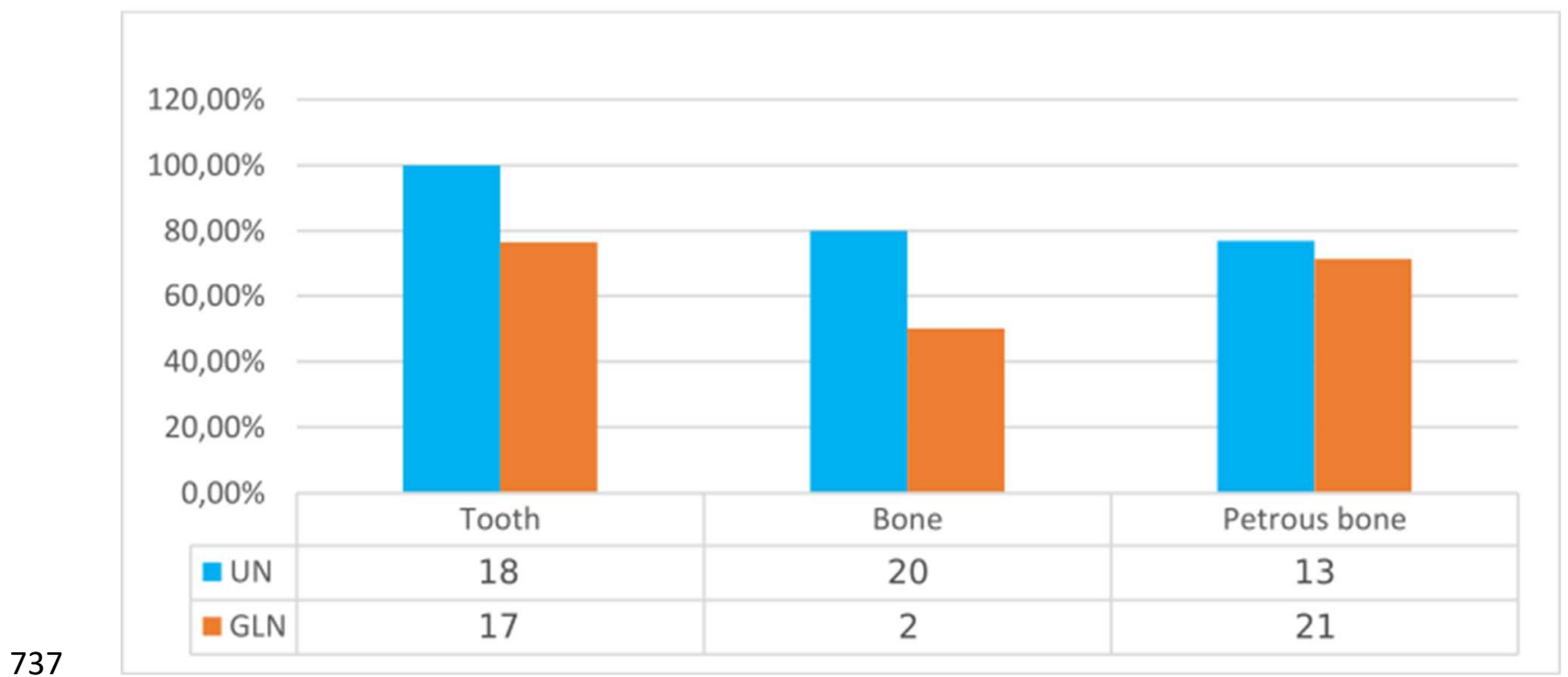

Figure S1 : Success rate in recovering mitochondrial DNA, according to site and anatomical elements. In blue UN: Urville-Nacqueville and in orange GLN: Gurgy 'Les Noisats' 

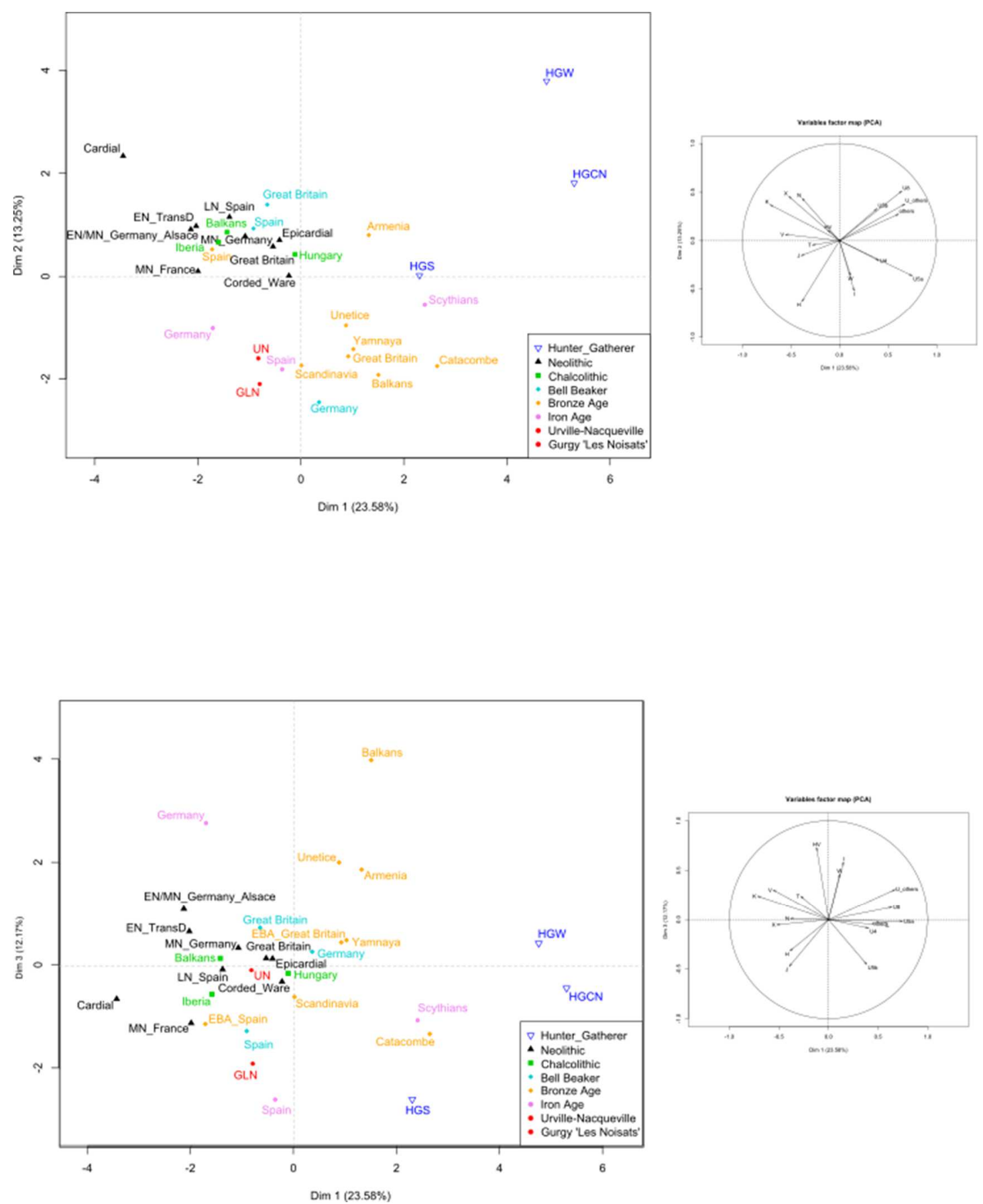

Figure S3 : Principal component analysis (PCA) on the ancient mtDNA dataset, taking into account potential maternal kinship. A) PCA performed on haplogroup frequencies, built with PC1 and PC2 B) PCA performed on haplogroup frequencies, built with PC1 and PC3. HGCN: Huntergatherers from Central Europe; HGW: Hunter-gatherers from Western Europe; HGS: Huntergatherers from Southern Europe; CAR: Cardial; EN: Early Neolithic; MN: Middle Neolithic; LN: Late Neolithic; UN: Urville-Nacqueville; GLN: Gurgy 'Les Noisats'. 

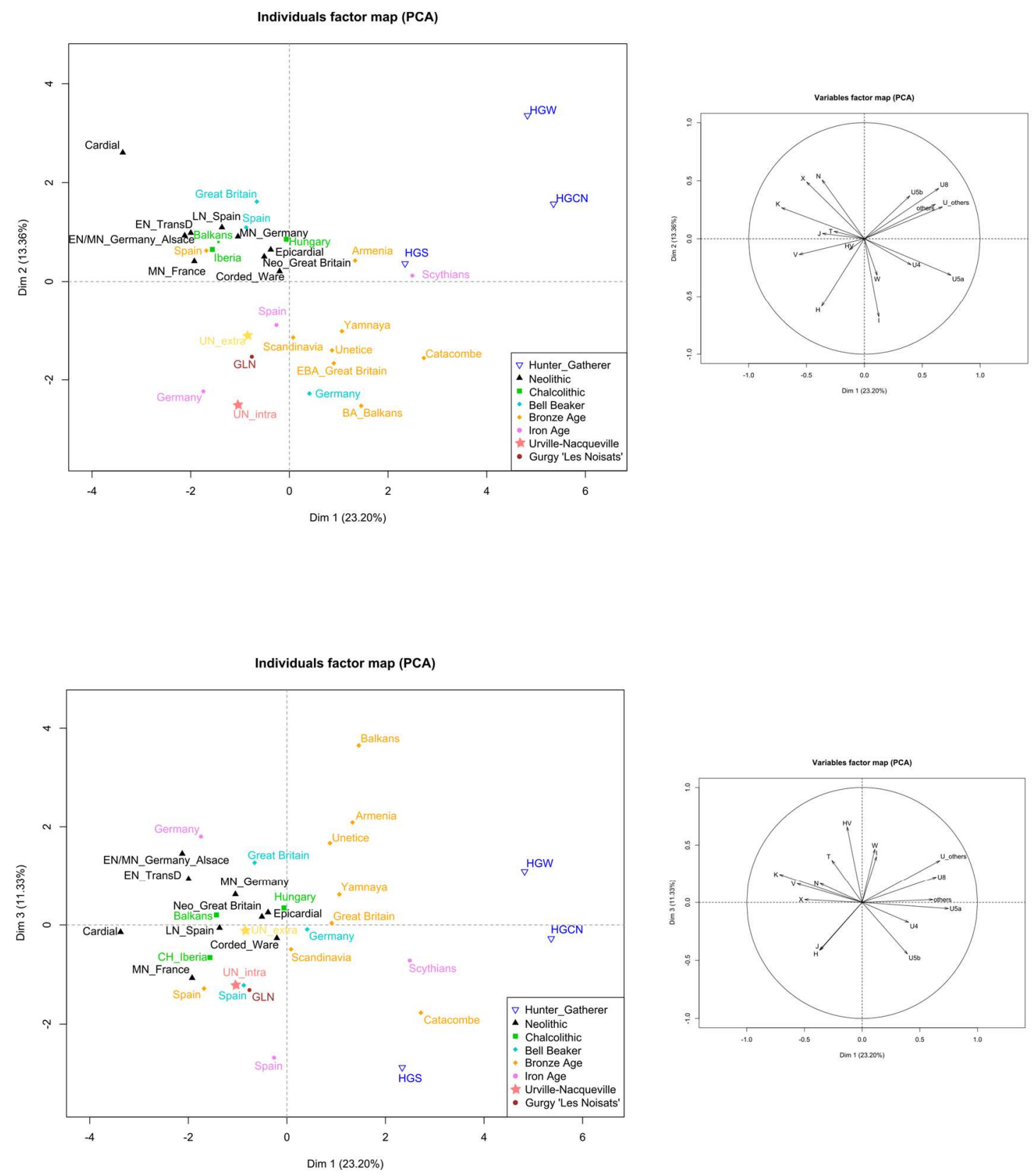

Figure S3 : Principal component analysis (PCA) on the ancient mtDNA dataset, considering

UN as two groups. A) PCA performed on haplogroup frequencies, built with PC1 and PC2 B) PCA performed on haplogroup frequencies, built with PC1 and PC3. HGCN: Hunter-gatherers from 